\title{
Applied autonomous maintenance in the improvement of production quality: A case study
}

\author{
Cloves Wanderlande Torres Ferreira ${ }^{1}$; Jandecy Cabal Leite ${ }^{2}$ \\ ${ }^{1}$ Universidade Federal do Pará (UFPA). Campus Guamá Rua Augusto Correa No 01. Belém, PA. CEP 66075-110. Caixa Postal 479. \\ (cloves_torres11@hotmail.com) \\ ${ }^{2}$ Instituto de Tecnologia e Educação Galileo da Amazônia (ITEGAM). Av. Joaquim Nabuco No 1950. Centro, Manaus - AM, CEP: \\ 69005-080, (jandecy.cabral@itegam.org.br)
}

\begin{abstract}
The global scenario of the major economic developed countries is a reflection of technological advances making companies competing and strategists. The objective of this paper is to analyze the current maintenance situation at the company studied, identifying technical actions with immediate results and implementing the Autonomous Maintenance (MA) to improve the performance of a white line production process in a company at the Industrial Pole of Manaus. It was achieved with this, to identify the problem in its early stages and encourage the operator to have a closer relationship with his process by detecting and resolving the possible failures. The data used were obtained from the company during the period from December 2015 until July 2016, and are related to stops identified by a leak detector. The applied methods are the qualitative and quantitative approach. The information was obtained from employees of the assembly line area, production leaders and representatives of maintenance, through questionnaires, obtained from data files (document analysis) and a history of reports of problems. The results achieved are: the application of the MA in the company, the increase in productivity; reducing the stop time of the production line, the availability of maintenance personnel to solve other problems, greater involvement of operators with their activity, less time in the implementation of equipment maintenance; greater involvement between maintenance and production. These improvements turned the company more competitive and sustainable.
\end{abstract}

Keywords: Maintenance; Total Productive Maintenance (TPM); Production and Technological Advance.

\section{INTRODUCTION}

The company maintenance has become a strategic function for competitiveness. The charging is more and more for results and today are being introduced in all sectors of society technology and innovative practices which have as aim to achieve new concepts of maintenance and that will have consequences in the performance of equipment and systems; try to find improvement of the performance of maintenance by the reduction of its cost and the level of failures.

Maintenance is the aim of all discussion. It always becomes hampered that some failure takes place in the productive system. The failure is the main variable and the reason of all study in reliability and it has direct relation with various aspects of maintenance [1].

The present research focus on its study of the implementation of autonomous maintenance in some posts of work of a company of Industrial Area of Manaus (IAM) with the aim to promote improvement in the process of maintenance and, consequently in the process of production, with focus on the continuous improvement once the ideal maintenance would be the one which generated $0 \%$ of failures in the equipment, as $100 \%$ efficient and efficient but we know that it is something impossible to get.
This study focused on the type of maintenance to be implemented in the company and the reduction of the number of the stops which this type of maintenance would entail since the current scenario of the company is of intense pace of production. It was considered that the application of autonomous maintenance in some posts of work would considerably reduce the number of stops caused for some equipment failure of this work station; the autonomous maintenance brought benefits with the increase in productivity; the reduce of line production stop time; the disposal of the maintenance staff to solve other problems; a great involvement the operators with their activity; a minor time in the maintenance implementation and the equipment and greater involvement between the maintenance and the production. The aims of this research consist on a surveying of the current situation, identifying technical actions with immediate results and actions of medium and long term to its improvement on the performance. And some specific aspects were studied as improvement of the comprehension of equipment functioning or system and development of group work with highly positive results on the analysis and solution of problems.

\section{BIBLIOGRAPHIC REVIEW}

\section{II.1. MAINUTENANCE}

That machines and equipment used are consistent covering more advanced technology and, depending on that, the companies 
Cloves W. T. Ferreira, Jandecy C. Leite / ITEGAM-JETIA Vol.02, No 07, pp.17-27. Setembro, 2016.

need a more efficient approach of maintenance than the traditional activities of maintenance [2]. In accordance with [3], there are five concepts of maintenance up to come the current concept which aims to zero failure and zero breakdown of machinery, zero defects on the products and zero loss on the process, as:

Primitive: Maintain and repair when the machine or the equipment breaks;

Traditional: Maintain and repair the machine or the equipment as brand new;

Evolved: Maintain and repair the level higher of production volume, through higher interaction between the activities of maintenance and operation;

TPM Phase 1: Maintain and repair the maximum levels of productivity (income/costs);

TPM Phase 2: Maintain and repair the pace of improvements carried out, changes made and transformations too.

It is perceived that the evolution of the maintenance started in a time before the II World War to the present day, came from the need of the companies to be more competitive with less costs and more productivity. It is clear that with the evolution of concepts maintenance itself is not only an isolated activity, but systematic which involves people and processes of a company, with the aim of improvement in the results of corporations [4].

Some time ago, the predominant concept was that the mission of maintenance was to restore the original conditions of equipment/systems. Nowadays the mission is to guarantee the disposal of the function of the equipment and facilities in order to attend the process of production or service with reliability, security, preserving the environment and reasonable costs [5].

Maintenance to be strategic needs to be focused on business results of the organization. It is necessary by the whole not to be only efficient to be good; that is to say, it is not enough simply to repair the equipment or install it as fast as possible, but it is necessary mainly to keep the function of the equipment available to the operation, reducing the stop probability in the not planned production [5].

\section{II.2. TYPES OF MAINTENANCE}

Some basic practices define the main types of maintenance which is divided into six basic types described by [5] who say that corrective maintenance not planned: is the correction of failure or of the performance minor than the expected right after its occurrence; there is no time to plan the use of labor force, tools, nor replacement material, if applicable; in this type of maintenance, two conditions are observed: faulty performance of the machine or equipment and failures themselves:

Planned Corrective Maintenance: is the type which is carried out with minor performance than expected, but with management decision; this type of maintenance has lower cost and it is undertaken faster, also safer than the non planned one. Those activities include a number of steps, for instance, detection of failures, the isolation, the decomposition, the replacement, reassembly, tests etc. [6].

Preventive Maintenance (PM): undertaken in order to reduce or prevent from failure of equipment; it is time-base performed independently of equipment of component conditions; this type of maintenance allows the good condition of management of activities and the quantity of resources, despite the prevention of the material consumption and others. According to [7] PM is an efficient way to guarantee the good performance of the equipment.

Detective Maintenance: In accordance with [8] it is only applied to concealed defects or unrevealed failures and hidden ones which normally only affect protection devices.

Maintenance Engineering: According to [5] modern analytical techniques are adopted and also prevention of failures which bring a cultural change in the way of thinking maintenance, with some actions like: to seek for basic causes of breakdowns, change permanent situations of machine performance and equipment, improve the parameters and the systematic cares and control of equipment.

\section{II.3 TOTAL PRODUCTIVE MAINTENANCE (TPM)}

The Total productive Maintenance, designed shortly as TPM, is the set of activities where it is kept the commitment related to the result. To [9], many organizations have implemented TPM as a tool which allows to maximize the efficiency of equipment through creation and maintenance of ideal relationship between people and their machines. Its excellence is at reaching the maximum efficiency from the system of production. To maximize the total useful life-cycle of the equipment it is necessary to grasp the existing resources to try to find zero loss. TPM demands the participation of all elements in the production chain, from the operator of equipment, passing to the maintenance staff and middlemen headships to the high staff of management [10].

According to [11], the aim of TPM is to improve productivity and quality along with the moral improvement of the employees and satisfaction with the work. TPM has become one of the most popular strategies of maintenance to guarantee machinery highest reliability, once it is considered as integrated part of Lean Manufacturing [12].

TPM is a strategy of manufacturing of world class which conducts to the manufacturing close to the ideal condition, with zero to down of time, zero defect, lean production, just-in-time (JIT) and leader of competitive cost in order to gain competitive advantage. TPM is an innovative approach well known of the maintenance strategy which has the potential to improve the global efficiency of equipment [13].

\section{II.4 AUTONOMOUS MAINTENANCE (AM)}

[14] affirm that AM is an activity of breakdown preventive maintenance which is directly treated by the production operator. It is done because the operator has the sensibility of a little change which takes place in the machine under his responsibility. 
$\mathrm{AM}$ is the independent maintenance undertaken by the operators of machines and for technicians dedicated to the maintenance. This is a core concept of TPM which gives more responsibility and authority to operators and releases the technicians to their works of maintenance in a more preventive way. This means that the operators execute the simplest routine maintenance works and certain activities of equipment maintenance. This allows them to feel greater ownership for their work and they gain more control as things are done and improvements can be taken [12].

AM can be also translated as a training process of operators, with the aim of making them capable of promoting, in their place of work, changes which guarantee high productivity levels, therefore the autonomous maintenance means to change the concept of "I manufacture, you repair" to "I myself take care of my equipment" [10].

The pillar of AM has the aim to develop in operators care and zeal with their machines and equipment, making them to supervise and detect any existing eventual problem. In this pillar, operators have autonomy to action, self-management and control of their means of production [4]. According to [3], AM pillar is divided into seven stages or steps, as follows:

Step 1 (Initial Clean): in this step operators clean and inspect their machines and equipment with the aim to solve possible problems at short-term; by doing so the operator gets to know better his equipment and to take care of it; in this step generally also it is adopted the opening of labels (described in details in item 6.5), which has the aim to help in the detection of machinery and equipment problems;

Step 2 (Eliminate dirt sources and inaccessible places): in this step it is worth striking the dirt sources and which can contaminate the operator or the work environment; in this step the inaccessible places must be eliminated, with the aim to facilitate the operation services and the maintenance;

Step 3 (Parameters of Cleaning and Greasing): the aim is to search for na optimal operating state in the workplace, with inspection and greasing standardization;

Step 4 (General Inspection): in this step the operators must be trained in basic maintenance on machinery and equipment; it is important the commitment of leaders from the areas of release of operators for those trainings;

Step 5 (Autonomous Inspection): it is the creation of procedures and of definitive equipment checklists;

Step 6 (Organization and Order): in this step is where S5 turns more evident and more used because it is about the organization surrounding the machines and equipment well as the correct use of resources, the checking of the layout, of the stock control, of area checking and other aspects;

Step 7 (AM Consolidation): it serves to consolidate the AM activities through the creation of an annual calendar of checking steps along with the improvement of operators'skill to take care of their machines and equipment.

\section{II.5 BASIS FOR TPM IMPLEMENTATION - 5S PROGRAM}

There are at least three practices which should be considered basic for maintenance: 5S; TPM and Multispecialization. The $5 \mathrm{~S}$ is the basis of quality, without a culture of $5 \mathrm{~S}$ it hardly has the environment which can generate a work with quality. The $5 \mathrm{~S}$ is defined for 5 words which define the main activities: Seiri, Seiton, Seiso, Seiketsu, Shitske and can be defined as a strategy to enhance and develop people to think of the common good. The implementation must come from the high administration of the company. That is a demonstration it looks after for the company and for the employees. To the definite implementation of $5 \mathrm{~S}$ is necessary that all employees to participate, from the president to the lowest occupation employee. [5]. 5S program, which came from Japan, is the basis for TPM in educational terms, bringing with it a proposal of change in the organizational culture and a greater participation of the group of professionals in awareness programs of the companies. $5 \mathrm{~S}$ is seen in a broad sense in the pillar of AM [4].

\section{MATERIALS AND METHODS}

The materials used, with the aim to consolidate the theoretical and practical basement, were obtained through real data surveying in the company. These data were collected in a period of seven months, December 2015 to July 2016, and the data analyzed in this research are the ones related to stops caused by the leak detector not interesting for this study the other ones.

To obtain data about the number of stops and the responsible sector for those stops surveys were conducted with the company collaborators who had experiences in practice with the issue researched emphasizing concepts of autonomous maintenance. These data were reorganized to attend the need of analysis of the case study at issue [15].

The universe of the research took place in EletroMAX, a household appliances company in Industrial Pole of Manaus (PIM, the short term in Portuguese). The name of the organization is fictitious in order to preserve the commercial image of it, upon request of the company.

The method, according to [16], is a set of systematic activities which allows to achieve the goal, knowledge, charting the way forward, detecting errors and helping the scientist's decisionmaking. The methods used in this study cover a qualitative and a quantitative approach and in this sense to present quantitative data to enlighten some aspects and qualitative ones to carry out the content analysis [17].

Primary and secondary sources of information were used, such as: information from employees of the assembly line area, leaders of production and maintenance representatives, generated via questionnaires and the secondary data were obtained in the company via archives (documental analysis) and accounts from background problems.

To achieve the goal and based on the theoretical fundaments, of exploratory type, leading questions were made in order to give greater familiarity with the process, characteristics and 
Cloves W. T. Ferreira, Jandecy C. Leite / ITEGAM-JETIA Vol.02, Nº 07, pp.17-27. Setembro, 2016.

limitations. Through bibliographic information related to TPM data processing was undertaken which is of great importance to the development of analysis and to its approval.

\section{RESULTS AND DISCUSSION}

IV.1 SURVEYING OF RESOURCE DATA
To obtain data about the number of stops and identify the responsible production sector surveys were conducted with collaborators and documental analysis was provided by the company in an interval of seven months. In these data all stops of the line are registered since December 2015 to July 2016. With obtained data it was designed a table which is below with only the data from stops related to leak detectors, as presented in Table 1 .

Table 1: Total of Stops.

\begin{tabular}{|c|c|c|c|c|c|c|}
\hline START & END & TIME & REASON & RESPONSIBLE & DATE & MONTHS \\
\hline $11: 30$ & $11: 33$ & 00:03 & Leak Detector & Process & $09 / 12 / 2015$ & December \\
\hline $14: 15$ & $14: 23$ & 00:08 & Leak Detector & Plant Engineering & $12 / 12 / 2015$ & December \\
\hline $15: 53$ & $15: 56$ & 00:03 & Leak Detector & Process & $15 / 12 / 2015$ & December \\
\hline $12: 45$ & $12: 55$ & $00: 10$ & Leak Detector & Plant Engineering & $27 / 01 / 2016$ & January \\
\hline $17: 03$ & $17: 07$ & 00:04 & Leak Detector & Process & $28 / 01 / 2016$ & January \\
\hline 07:06 & $07: 12$ & 00:06 & Leak Detector & Plant Engineering & $29 / 01 / 2016$ & January \\
\hline $07: 10$ & $07: 18$ & 00:08 & Leak Detector & Plant Engineering & $04 / 02 / 2016$ & February \\
\hline 13:05 & $13: 10$ & 00:05 & Leak Detector & Plant Engineering & 06/02/2016 & February \\
\hline $14: 18$ & $14: 24$ & 00:06 & Leak Detector & Plant Engineering & 07/02/2016 & February \\
\hline $12: 42$ & $12: 45$ & 00:03 & Leak Detector & Plant Engineering & $11 / 02 / 2016$ & February \\
\hline $14: 17$ & $14: 23$ & 00:06 & Leak Detector & Plant Engineering & $11 / 02 / 2016$ & February \\
\hline $07: 30$ & $07: 34$ & 00:04 & Leak Detector & Plant Engineering & $13 / 02 / 2016$ & February \\
\hline 11:05 & $11: 15$ & $00: 10$ & Leak Detector & Plant Engineering & $13 / 02 / 2016$ & February \\
\hline $15: 10$ & $15: 14$ & 00:04 & Leak Detector & Plant Engineering & $13 / 02 / 2016$ & February \\
\hline $17: 40$ & $17: 52$ & $00: 12$ & Leak Detector & Plant Engineering & $13 / 02 / 2016$ & February \\
\hline $07: 32$ & $07: 35$ & 00:03 & Leak Detector & Plant Engineering & $14 / 02 / 2016$ & February \\
\hline $15: 38$ & $15: 50$ & $00: 12$ & Leak Detector & Plant Engineering & $14 / 02 / 2016$ & February \\
\hline $16: 55$ & $17: 10$ & $00: 15$ & Leak Detector & Plant Engineering & $14 / 02 / 2016$ & February \\
\hline 09:40 & 09:43 & 00:03 & Leak Detector & Plant Engineering & $15 / 02 / 2016$ & February \\
\hline $13: 10$ & $13: 20$ & $00: 10$ & Leak Detector & Plant Engineering & $15 / 02 / 2016$ & February \\
\hline $13: 30$ & $13: 40$ & $00: 10$ & Leak Detector & Plant Engineering & $15 / 02 / 2016$ & February \\
\hline 09:10 & 09:15 & 00:05 & Leak Detector & Plant Engineering & $17 / 02 / 2016$ & February \\
\hline 09:30 & $09: 35$ & 00:05 & Leak Detector & Plant Engineering & $17 / 02 / 2016$ & February \\
\hline 09:57 & $10: 06$ & 00:09 & Leak Detector & Plant Engineering & $17 / 02 / 2016$ & February \\
\hline $15: 36$ & $15: 40$ & 00:04 & Leak Detector & Plant Engineering & $17 / 02 / 2016$ & February \\
\hline $16: 18$ & $16: 23$ & 00:05 & Leak Detector & Plant Engineering & $17 / 02 / 2016$ & February \\
\hline $17: 42$ & $17: 56$ & $00: 14$ & Leak Detector & Plant Engineering & $19 / 02 / 2016$ & February \\
\hline $17: 17$ & $17: 26$ & 00:09 & Leak Detector & Plant Engineering & $20 / 02 / 2016$ & February \\
\hline $12: 05$ & $12: 15$ & 00:10 & Leak Detector & Plant Engineering & $24 / 02 / 2016$ & February \\
\hline $12: 50$ & 13:00 & $00: 10$ & Leak Detector & Plant Engineering & $28 / 02 / 2016$ & February \\
\hline 09:13 & 09:18 & 00:05 & Leak Detector & Plant Engineering & $31 / 2 / 2016$ & February \\
\hline 09:05 & 09:08 & 00:03 & Leak Detector & Plant Engineering & $02 / 03 / 2016$ & March \\
\hline $10: 59$ & 11:04 & 00:05 & Leak Detector & Plant Engineering & $02 / 03 / 2016$ & March \\
\hline $13: 50$ & $14: 00$ & $00: 10$ & Leak Detector & Plant Engineering & $04 / 03 / 2016$ & March \\
\hline $07: 23$ & $07: 36$ & $00: 13$ & Leak Detector & Plant Engineering & 05/03/2016 & March \\
\hline
\end{tabular}


Cloves W. T. Ferreira, Jandecy C. Leite / ITEGAM-JETIA Vol.02, No 07, pp.17-27. Setembro, 2016.

\begin{tabular}{|c|c|c|c|c|c|c|}
\hline 13:14 & $13: 21$ & 00:07 & Leak Detector & Plant Engineering & $18 / 03 / 2016$ & March \\
\hline $16: 40$ & $16: 45$ & 00:05 & Leak Detector & Plant Engineering & $22 / 03 / 2016$ & March \\
\hline $10: 58$ & 11:04 & 00:06 & Leak Detector & Plant Engineering & $24 / 03 / 2016$ & March \\
\hline 07:00 & $07: 10$ & $00: 10$ & Leak Detector & Plant Engineering & $26 / 03 / 2016$ & March \\
\hline 07:23 & $07: 33$ & $00: 10$ & Leak Detector & Plant Engineering & $26 / 03 / 2016$ & March \\
\hline 07:58 & 08:10 & $00: 12$ & Leak Detector & Plant Engineering & $05 / 04 / 2016$ & April \\
\hline $14: 30$ & $14: 40$ & $00: 10$ & Leak Detector & Plant Engineering & $08 / 04 / 2016$ & April \\
\hline 07:37 & $07: 56$ & $00: 19$ & Leak Detector & Plant Engineering & $09 / 04 / 2016$ & April \\
\hline 09:28 & 09:57 & $00: 29$ & Leak Detector & Plant Engineering & $09 / 04 / 2016$ & April \\
\hline 10:40 & $10: 47$ & 00:07 & Leak Detector & Plant Engineering & $09 / 04 / 2016$ & April \\
\hline 07:00 & 07:08 & 00:08 & Leak Detector & Plant Engineering & $10 / 04 / 2016$ & April \\
\hline 07:20 & $07: 30$ & $00: 10$ & Leak Detector & Plant Engineering & $10 / 04 / 2016$ & April \\
\hline 09:50 & 09:58 & 00:08 & Leak Detector & Plant Engineering & $12 / 04 / 2016$ & April \\
\hline $14: 22$ & $14: 25$ & 00:03 & Leak Detector & Plant Engineering & $12 / 04 / 2016$ & April \\
\hline $12: 40$ & $13: 00$ & 00:20 & Leak Detector & Plant Engineering & $13 / 04 / 2016$ & April \\
\hline 13:24 & $13: 35$ & $00: 11$ & Leak Detector & Plant Engineering & $13 / 04 / 2016$ & April \\
\hline 16:05 & $16: 15$ & $00: 10$ & Leak Detector & Plant Engineering & $13 / 04 / 2016$ & April \\
\hline $11: 25$ & $11: 35$ & $00: 10$ & Leak Detector & Plant Engineering & $14 / 04 / 2016$ & April \\
\hline 08:10 & 08:20 & $00: 10$ & Leak Detector & Plant Engineering & $15 / 04 / 2016$ & April \\
\hline 09:42 & $10: 25$ & $00: 43$ & Leak Detector & Plant Engineering & $15 / 04 / 2016$ & April \\
\hline $13: 36$ & $13: 40$ & 00:04 & Leak Detector & Plant Engineering & $15 / 04 / 2016$ & April \\
\hline $13: 58$ & $14: 00$ & 00:02 & Leak Detector & Plant Engineering & $23 / 04 / 2016$ & April \\
\hline $16: 38$ & $16: 55$ & $00: 17$ & Leak Detector & Plant Engineering & $27 / 04 / 2016$ & April \\
\hline 07:00 & $07: 15$ & $00: 15$ & Leak Detector & Plant Engineering & $28 / 04 / 2016$ & April \\
\hline 07:20 & $07: 25$ & 00:05 & Leak Detector & Plant Engineering & $28 / 04 / 2016$ & April \\
\hline 11:20 & $11: 26$ & 00:06 & Leak Detector & Plant Engineering & $13 / 05 / 2016$ & May \\
\hline 08:03 & 08:05 & 00:02 & Leak Detector & Assembly Line & $16 / 05 / 2016$ & May \\
\hline 08:20 & $08: 22$ & 00:02 & Leak Detector & Assembly Line & $18 / 05 / 2016$ & May \\
\hline 13:05 & 13:07 & 00:02 & Leak Detector & Assembly Line & $20 / 05 / 2016$ & May \\
\hline $16: 15$ & $16: 30$ & $00: 15$ & Leak Detector & Plant Engineering & $27 / 05 / 2016$ & May \\
\hline 16:03 & $16: 15$ & $00: 12$ & Leak Detector & Plant Engineering & $30 / 05 / 2016$ & May \\
\hline $16: 20$ & $16: 28$ & 00:08 & Leak Detector & Assembly Line & $01 / 06 / 2016$ & June \\
\hline $11: 25$ & $11: 30$ & 00:05 & Leak Detector & Plant Engineering & 09/06/2016 & June \\
\hline 16:18 & $16: 25$ & 00:07 & Leak Detector & Plant Engineering & $14 / 06 / 2016$ & June \\
\hline $12: 37$ & $12: 40$ & 00:03 & Leak Detector & Plant Engineering & $16 / 06 / 2016$ & June \\
\hline $12: 49$ & 13:05 & $00: 16$ & Leak Detector & Plant Engineering & $16 / 06 / 2016$ & June \\
\hline $15: 15$ & $15: 18$ & 00:03 & Leak Detector & Manaus Energia & $16 / 06 / 2016$ & June \\
\hline 09:06 & 09:10 & 00:04 & Leak Detector & Plant Engineering & $20 / 06 / 2016$ & June \\
\hline 08:00 & 08:05 & 00:05 & Leak Detector & Process Engineering & $28 / 06 / 2016$ & June \\
\hline 09:05 & 09:15 & $00: 10$ & Leak Detector & Plant Engineering & $28 / 06 / 2016$ & June \\
\hline $10: 20$ & $10: 23$ & 00:03 & Leak Detector & Reflex & $05 / 07 / 2016$ & July \\
\hline
\end{tabular}

Total of stops: 10:46:00

Source: The Authors (2016). 
From the data of Table 1, Table 2 was generated in summarized form with the amount of seven-month stops of the line for any failure in the production including the one in the study and the stops caused by the leak detector in order to have a quantitative idea of variables and of the influences they have in total time of stop in the company in Table 1 . The need of conducting a study on those stops turned of great importance when the values that were taken to chart of Picture 1 were identified which gave us an overview of the effect of those stops. It was found that the Maintenance was the sector which took on the major responsibility for the stops on the production line on account of a reason which could be prevented in a simple way.

Table 2: Detectors x Variables.

\begin{tabular}{c|c|c|c}
\hline \multicolumn{4}{c}{ Stops caused for: } \\
\hline \multicolumn{2}{c}{ Detectors } & \multicolumn{2}{c}{ Variables } \\
\hline December & $00: 14$ & December & $00: 52$ \\
\hline January & $00: 20$ & January & $00: 57$ \\
\hline February & $03: 07$ & February & $14: 48$ \\
\hline March & $01: 09$ & March & $04: 47$ \\
\hline April & $04: 13$ & April & $08: 11$ \\
\hline May & $00: 39$ & May & $04: 41$ \\
\hline June & $01: 01$ & June & $06: 56$ \\
\hline July & $00: 03$ & July & $01: 06$ \\
\hline
\end{tabular}

Source: The Authors (2016).

The chart of Figure 1 relates the total value of stops on the production line independently of equipment, sector or operation, with a stop caused by leak detector, the focus of this research. It was observed that the stops of the line between the months of February and April are more pronounced, nevertheless the others are considered stops of critical status, those stops could be avoided if AM was implemented in the use of that equipment.

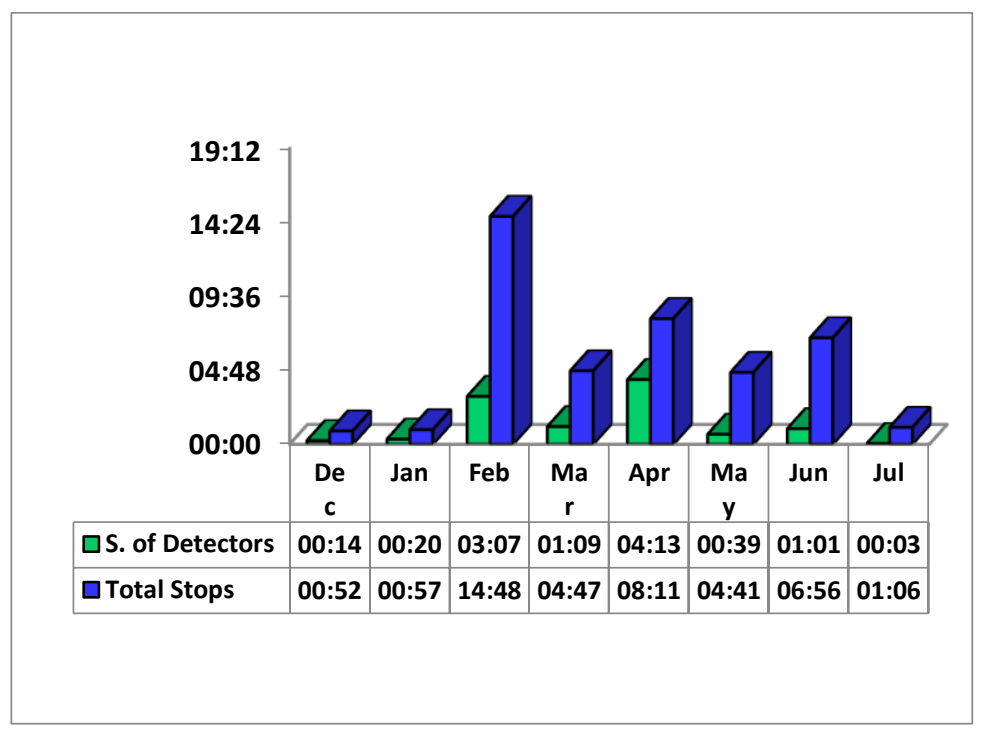

Figure 1: Chart of Stops.

Source: The Authors (2016).

A questionnaire was made and it was answered by the person who is responsible by the maintenance of that sector and it was possible to have the following information as shown in Chart 1. 
Chart 1: Questionnaire of Maintenance.

\begin{tabular}{|c|c|}
\hline Questions & Answers \\
\hline $\begin{array}{c}\text { What is the interval from the } \\
\text { first maintenance and the last } \\
\text { one? }\end{array}$ & $\begin{array}{c}\text { The first is at 7:00 a.m. and } \\
\text { the next is in the break of } \\
\text { lunch at 12:00. }\end{array}$ \\
\hline $\begin{array}{c}\text { What is the most frequent } \\
\text { problem registered in the } \\
\text { equipment? }\end{array}$ & Dirt caused by tip clogging. \\
\hline $\begin{array}{c}\text { What is the action to correct } \\
\text { the fault? }\end{array}$ & $\begin{array}{c}\text { Clenaing of the hose and filter } \\
\text { change. }\end{array}$ \\
\hline $\begin{array}{c}\text { From the total of attendance, } \\
\text { how many necessarily are } \\
\text { more complex technical } \\
\text { problems not related with } \\
\text { the cleaning of the } \\
\text { equipment? }\end{array}$ & $\begin{array}{c}\text { From the total of attendance } \\
\text { about 5\% the remainder are } \\
\text { problems related to the } \\
\text { cleaning. }\end{array}$ \\
\hline $\begin{array}{c}\text { What are the effects whether } \\
\text { this maintenance does not } \\
\text { take place? }\end{array}$ & Stop of the Prodution line. \\
\hline
\end{tabular}

Source: The Authors (2016).

\section{IV.2 CHARACTERISTICS OF THE PROCESS}

The leak detectors are strategically located in four points circled in yellow in the production line, as shown on the layout of Figure 2. At those points there are inspections of quality made by operators and any abnormality, or not conformity existing in this operation carried out in the procedure, it is undertaken o procedure of withdrawing the product from the production line and it is sent to rework, but if there is a simultaneous failure of the four leak detectors, there would be a probability of a final product to present a serious problem.
The gas injected into the compressors in the air conditioners responsible by the cooling of it would leak without the registration of the leak detector and the air conditioner would work in reverse function, that is to say, instead of cooling the place, it would get warm. This problem is unlikely to happen, but the hypothesis is not discarded and if this problem would happen, there would be a damaging to the quality of the product on the market, moreover the total client dissatisfaction with the brand.

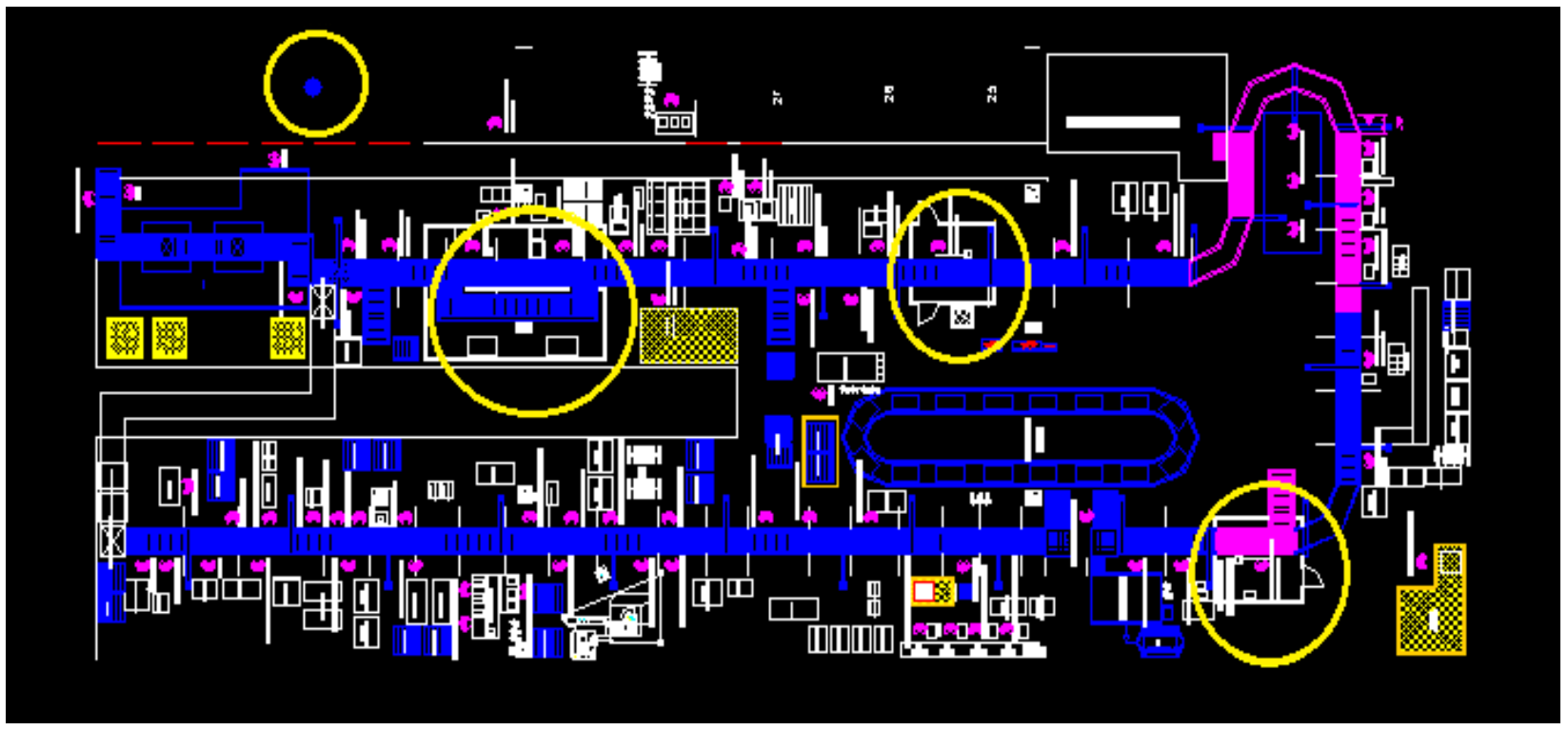

Figure 2: Layout of the Production Line.

Source: The Authors (2016). 
Cloves W. T. Ferreira, Jandecy C. Leite / ITEGAM-JETIA Vol.02, Nº 07, pp.17-27. Setembro, 2016.

\section{IV.3 EQUIPMENT OPERATION AND DESCRIPTION}

The leak detector, as shown in Figura 3, is also known as Assurance, an American company located in East Syracuse, New HLD4000 Halogen Leak Detector. It is an equipment from Quality York.

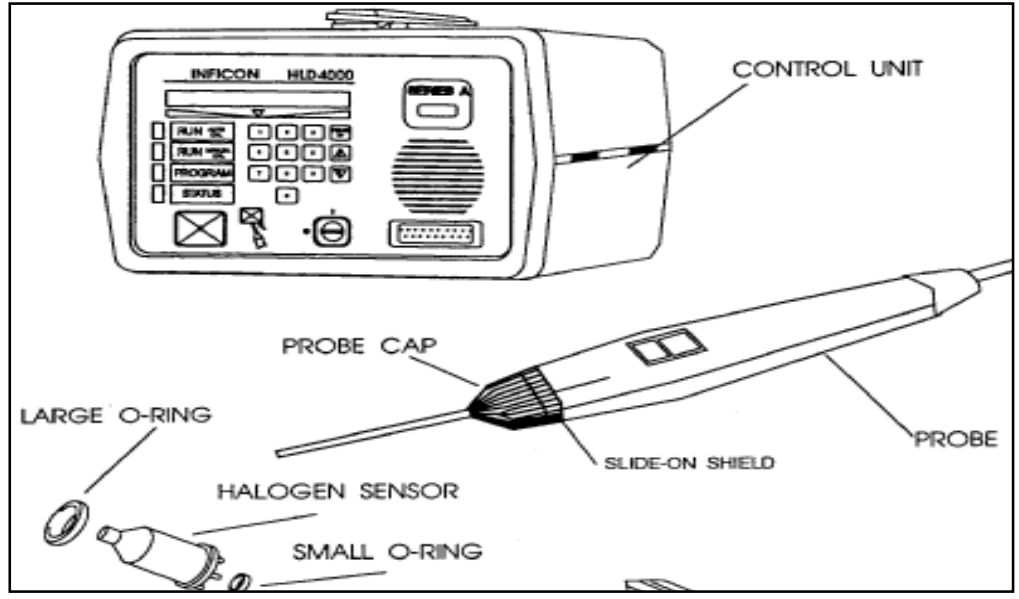

Figure 3: Detector and its Peripherals.

Source: The Authors (2016).

The HLD 4000 is an equipment which was designed to detect any leak of gas refrigerant R-22. This equipment has an internal sensor which in contact with that gas, activates a siren which emits a sound alerting the operator of a possible leak of gas. The leak detector has some peripherals, as seen on Fig. 3.

- probe cap - probe protection;

- slide-on shield - probe sliding protection;

- probe;
- large o-ring and small o-ring - sealing;

- control unit;

Those peripherals are the interesting part of this study because the maintenance of them would reduce in $95 \%$ of the stops caused by the detectors. The maintenance of these peripherals is summed up basically in cleaning, the way that cleaning can be accomplished is described step to step as shown in Figure 4.

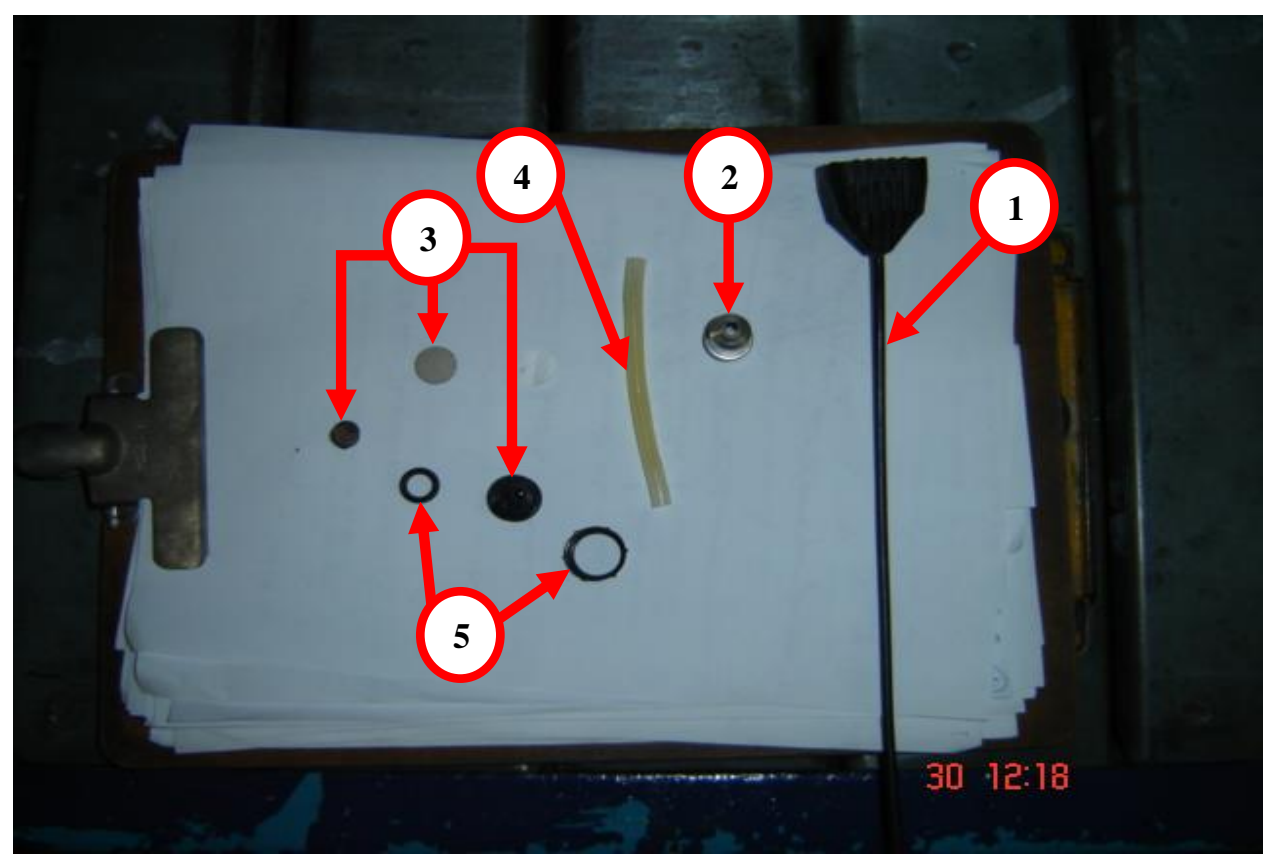

Figure 4: Picture of Peripherals.

Source: The Authors (2016). 
These are peripherals which are responsible by the great number of stops in the production line: 1) Probe; 2) Gas Sensor R22; 3) Filters; 4) Inner hose of the probe; 5) Seals.

The leak detector has a probe by which the air is sucked from the environment, in this probe there are three filters, two seals, one huger than the other and other inner hose. The functioning of it in places where there are dust residues can undermine the functioning due to filters blockage which can obstruct the air from passing and also from the gas R-22 passing to the sensor that detects the leak.

Figure 5 shows how the filers are when there is any dust residue in its parts.

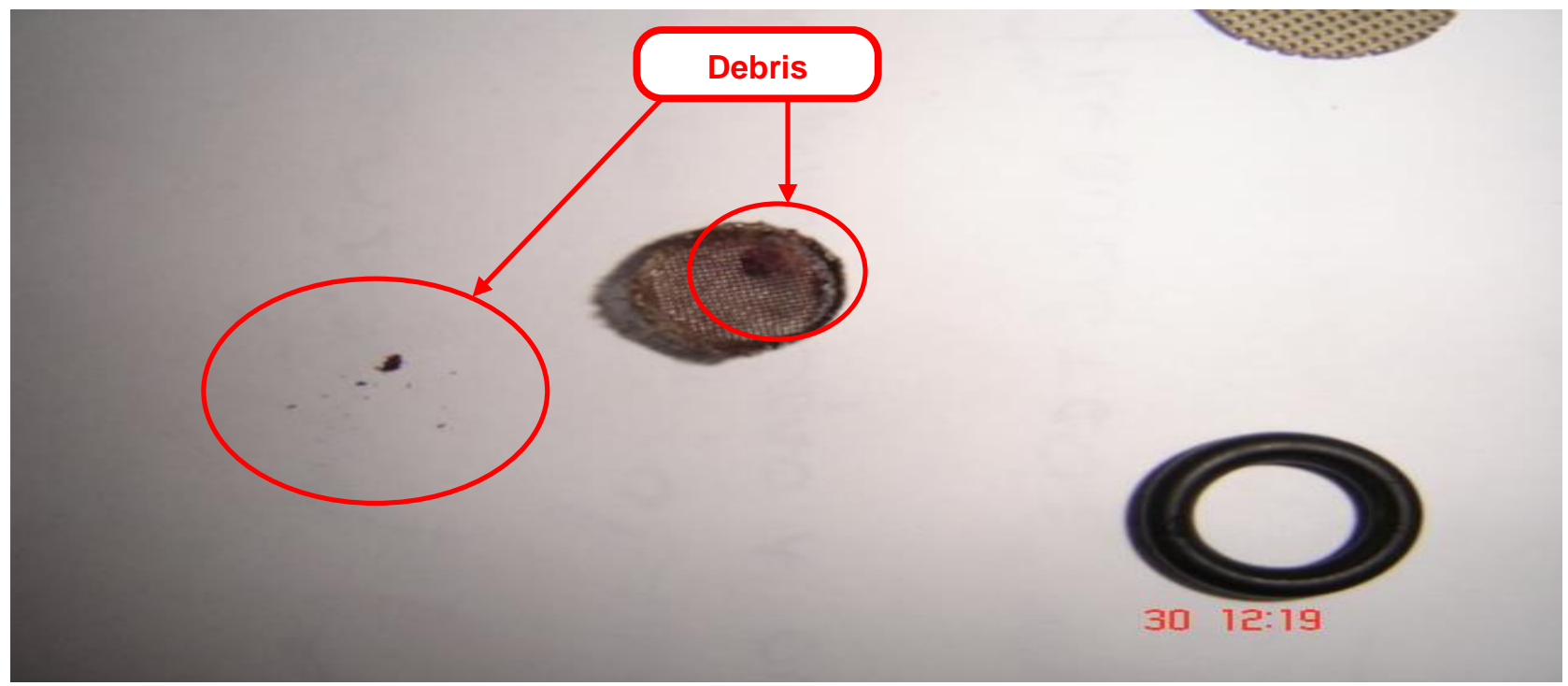

Figure 5: Picture of Filters with Debris. Source: The Authors (2016).

\section{IV.4 RESULTS ANALYSIS}

After the analysis of data and check by questionnaire filled in by the maintenance staff, there was evidence that all the calls for maintenance attendance of stop in the line caused by the leak detector, only $5 \%$ of calls, were to solve stops caused by more technical problems the remaining, about $95 \%$, were stops caused by impurities, or better, for dirt particles in the place and it could be avoided by simple actions.

The failures generally take place by factors such as: errors on the manufacturing, of assembling, of operation or maintenance, greasing or inadequate refrigeration, dirt, strange objects, wedge, leaks, deformations, broken, adverse environmental conditions, vibration, pressure oscillation, of temperature and of tension, incorrect torque, rust, corrosion, obstruction of ducts and also for collisions [1].

AM often does not require a technical knowledge about a specific maintenance equipment to be performed. Frequently knowing only some peripherals of the equipment we can avoid a number of damages with small preventative attitudes, grooming with the work place along with the cleaning of the equipment or of tools which are used in an operation or process once it is of a great return concerning to the lifetime of the equipment.

According to [18] the dirt particles, the debris and the strange materials are causes of defects, disqualification, empty runs, temporarily stops, being cause of various problems in the workplace.

Analyzing the chart of time of stops it was possible to detect that the Plant Engineering or Maintenance had the responsibility of $46 \%$ of all stops in the factory as shown in the chart of Figure 6.

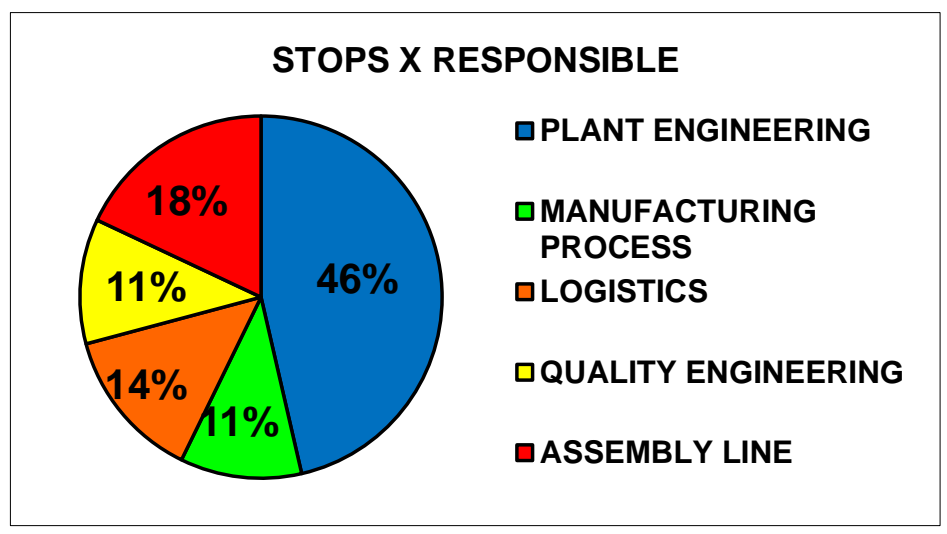

Figure 6: Chart of Stops x Responsible.

Source: The Authors (2016).

The need of having a focused work with the aim of reducing the quantity of time of stops became interesting not only for the researcher but also the senior management, making the case study interesting for all parts. 
From the obtained information with the maintenance responsible for the sector as seen in chart $\mathrm{G}$ where he mentions that $95 \%$ of attendance are exclusively for cleaning maintenance of equipment. It was generated a chart where it is taken in consideration that $95 \%$ of stops in the line related to equipment here mentioned could be avoided and the new values are in chart of Figure 7 as follows.

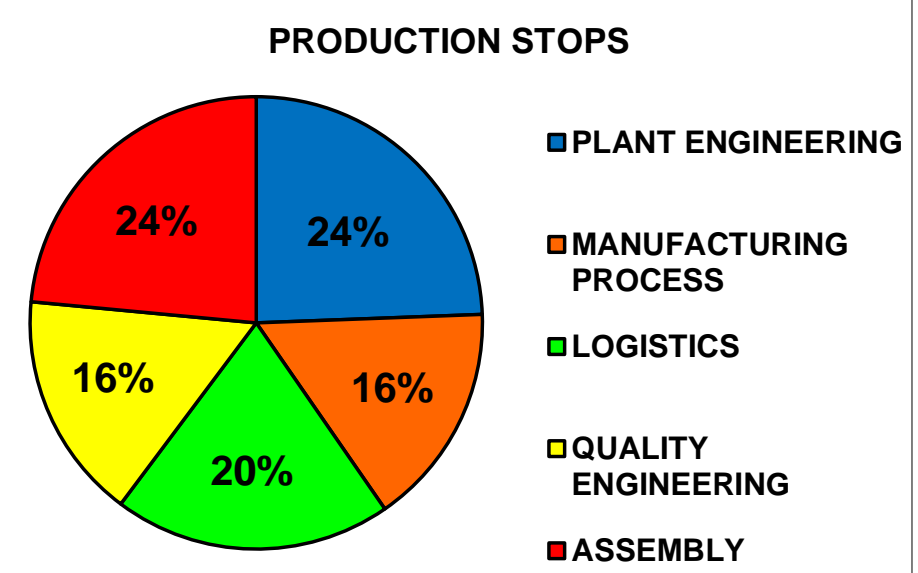

Figure 7: Chart of Production Stops.

Source: The Authors (2016).

Considering the new values, we verified that there is a fall of $22 \%$ on the percentage of stops in the sector of Plant Engineering, that is to say, before the study in that sector, the percentage was of $46 \%$ and it falls considerably to $24 \%$, a value that animates any group which is working to have results related to the improvement.

Summing up, the analysis was useful to diagnose a critical problem which at the end can be minimized with a simple and feasible solution enough, a suggestion with the changes suggested in this case study are all true and were made by using real and precise values.

\section{CONCLUSION}

This study the most important sector of a company has machinery to put in function, but it does not have the attention it should. This article offers a suggestion of improvements to the process of maintenance and with the application of AM it was possible to observe the reduction of the number of stops in the production line and so it reached the aim to make a survey of the current situation of maintenance, identifying the technical actions with immediate results presenting an improvement of performance right there. To obtain data about the number of stops, surveys with the collaborators of the company were made and so it was possible to have measurable data to the justifying of AM implementation in the sector, more precisely in some points of the production line. The study sought to clarify what the collaborator should do to a better adaptation at work by using as correct as possible his knowledge and space. With the implementation of AM, the abnormalities were identified in their initial phase making the collaborators to get close to the process and when it was possible solving the problems in a short term, by checking and having zeal to the equipment manipulated and then resulting in a final product with quality.

The results achieved were the increase of productivity; the reduction of stop time of the production line; the disposal of the maintenance staff to solve other problems; greater involvement of the operators with their activity; a minor time on the execution of the maintenance this equipment between the maintenance and the production and the final product with quality with interesting results and raised issues among the leaders of the production because of the lack of information and the difficulty of their improvement or changing of opinion. It was observed the need of further studies about the comprehension of culture and the organizational knowledge of the collaborators to encounter the resistance to accept the implementation of AM in the company.

\section{ACKNOWLEDGMENTS}

The authors acknowledge the Institute of Technology Galileo of Amazon (ITEGAM), the Federal University of Para (UFPA) for their support for performing this work.

\section{REFERENCES}

[1].N`DONGA, João Zola. Gestão de manutenção orientada à confiabilidade de componentes de aviação da força aérea de nacional de angola (FANA). Instituto Militar de Engenharia. Rio de Janeiro, RJ. 2010.

[2].BAYSAL, Mehmet Emin; SÜMBÜL, Mehmet Onur; EKICIOĞLU, Erdem. A total productive maintenance implementation in a manufacturing company operating in insulation sector in Turkey. IEEE The Sixth International Conference on Modeling, Simulation, and Applied Optimization ICMSAO'15. Istanbul, Turkey, 2015.

[3].RIBEIRO, H. Desmitificando a TPM: Como implantar o TPM em empresas fora do Japão. São Caetano do Sul: Ed. PDCA, 2010.

[4].FIDELIS, Nordana Tonaco Santos, et. al. O papel da manutenção autônoma no processo de implantação da TPM em uma empresa do setor automobilístico. XXXV Encontro Nacional de Engenharia de Produção: Perspectivas Globais para a Engenharia de Produção. Fortaleza, CE, 2015.

[5]. KARDEC, A; NASCIF, J. Manutenção: função estratégica. 3. ed. Revisada e ampliada. Rio de Janeiro: Qualitymark, Petrobras, 2009.

[6].GAO, Bocheng et al. Corrective maintenance process simulation algorithm research based on process interaction. IEEE Prognostics and System Health Management Conference. Beijing, China, 2012.

[7].ZHOU, Xiaojun; et al. A preventive maintenance model for leased equipment subject to internal degradation and external shock damage. Reliability Engineering \& System Safety. Vol. 154, 2016. 
[8].ETI, C. Mark; OGAJI, S.O.T.; PROBERT, S.D. Strategic maintenance-management in Nigerian industries. Applied Energy. Vol. 83, 2006.

[9].BON, Abdul Talib; PING, Lim Ping. Implementation of Total Productive Maintenance (TPM) in automotive industry. IEEE, Symposium on Business, Engineering and Industrial Applications ISBEIA. Langkawi, Malaysia, 2011.

[10].YAMAGUCHI, Carlos Toshio. TPM-Manutenção produtiva total. Instituto de Consultoria e Aperfeiçoamento Profissional - ICAP DEL REI. São João Del Rei, MG. 2005.

[11].KART, Özge; KUT, Alp. An implementation of real time total productive maintenance software. IEEE, International Conference on Information Society. London, 2014.

[12].RAHMAN, Chowdury ML. Assessment of total productive maintenance implementation in a semiautomated manufacturing company through downtime and mean downtime analysis. Industrial Engineering and Operations Management (IEOM), 2015 International Conference on Engineering - IEEE. Dubai, 2015.

[13].NG, K. C.; GOH, G. G. G.; EZE, U. C. Barriers in total productive maintenance implementation in a semiconductor manufacturing firm: A case study. IEEE International Conference on Industrial Engineering and Engineering Management. Hong Kong, 2012.

[14].KULKARNI, A. and DABADE, B. M. Investigation of Human aspect in Total Productive Maintenance (TPM): Literature Review, International Journal of Engineering Research and Development, Volume 5, Issue 10, 2013.

[15].YIN, Robert K. Case Study Research: Design and Methods. SAGE Publications Inc. 5a. ed. USA. 2014.

[16].MARCONI, M. de A.; LAKATOS, E. M. Fundamentos de metodologia científica. 7a ed. São Paulo: Atlas, 2010.

[17].PRODANOV, Cleber Cristiano; FREITAS, Ernani Cesar de. Metodologia do trabalho científico: métodos e técnicas da pesquisa e do trabalho acadêmico. 2. Ed. Novo Hamburgo, RS. Feevale, 2013.

[18].KARDEC, Alan Kardec e RIBEIRO, Haroldo. Gestão Estratégica e manutenção Autônoma. Qualitymark Editora LTDA. 2002. 